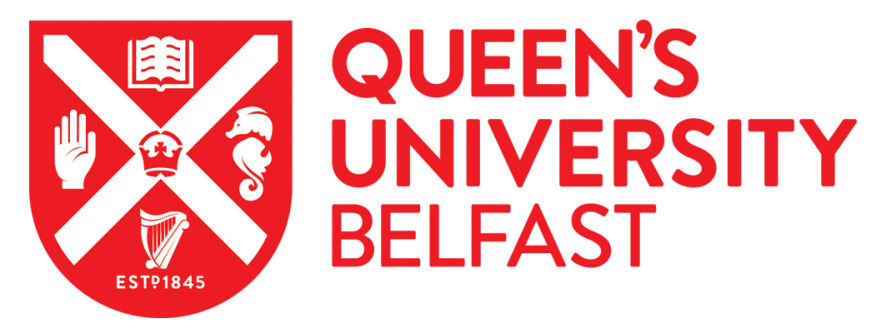

\title{
Cooperation and Conflict between Governor and poleis in the Verrines
}

Pfuntner, L. (2015). Cooperation and Conflict between Governor and poleis in the Verrines. Phoenix, 69(3/4), 355-375. https://doi.org/10.7834/phoenix.69.3-4.0355

\section{Published in: \\ Phoenix}

Document Version:

Publisher's PDF, also known as Version of record

Queen's University Belfast - Research Portal:

Link to publication record in Queen's University Belfast Research Portal

Publisher rights

(c) The Classical Association of Canada

\section{General rights}

Copyright for the publications made accessible via the Queen's University Belfast Research Portal is retained by the author(s) and / or other copyright owners and it is a condition of accessing these publications that users recognise and abide by the legal requirements associated with these rights.

Take down policy

The Research Portal is Queen's institutional repository that provides access to Queen's research output. Every effort has been made to ensure that content in the Research Portal does not infringe any person's rights, or applicable UK laws. If you discover content in the Research Portal that you believe breaches copyright or violates any law, please contact openaccess@qub.ac.uk. 

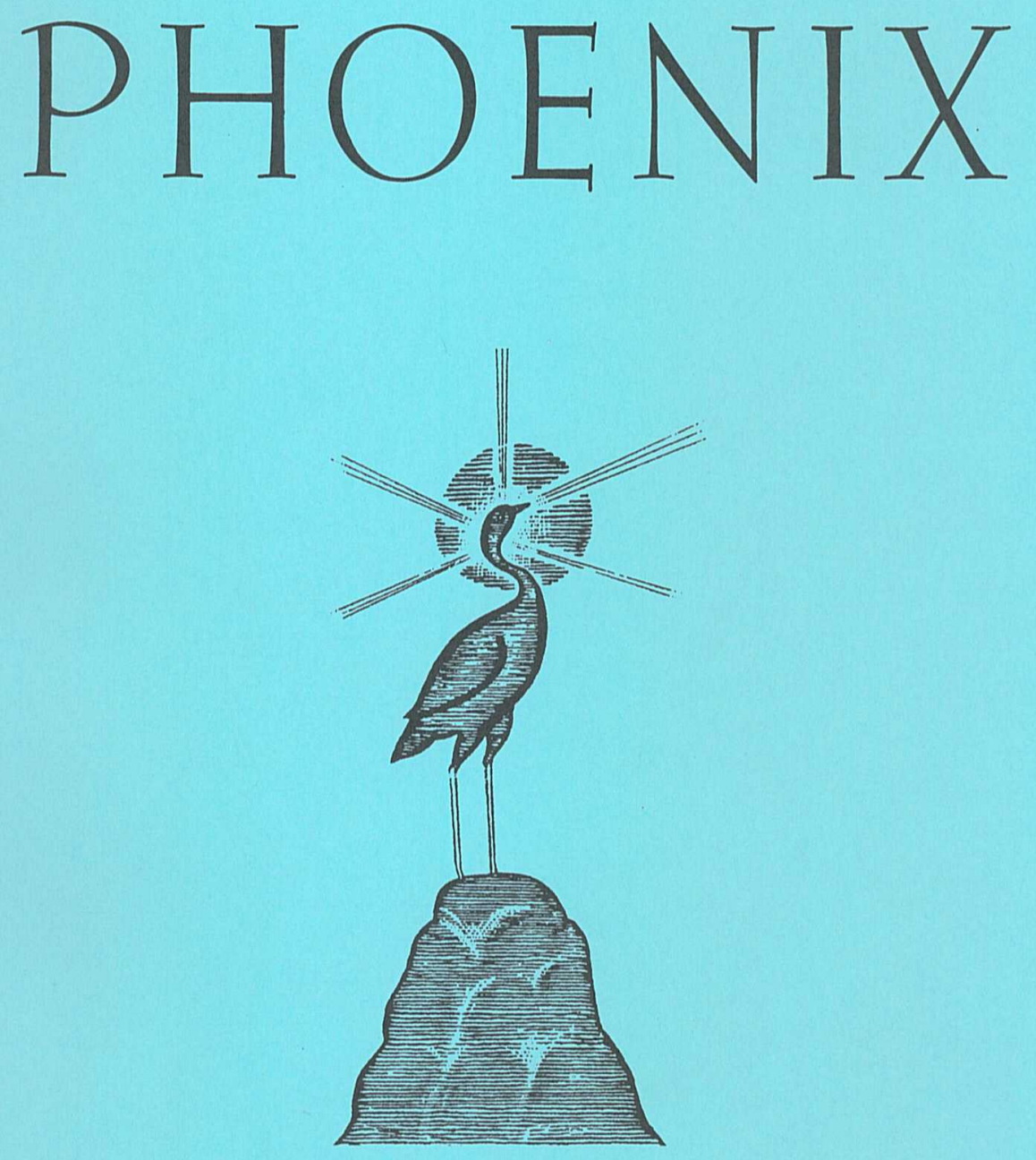

LXIX No. 3-4, Fall-Winter/automne-hiver 2015

Classical Association of Canada Société canadienne des études classiques 


\section{COOPERATION AND CONFLICT BETWEEN GOVERNOR AND POLEIS IN THE VERRINES}

\section{Laura Pfuntner}

\section{READING THE VERRINES FROM A SICILIAN PERSPECTIVE}

$\mathrm{I}$ B.C., in his first appearance as a prosecutor, Cicero presented his case against Gaius Verres, governor of Sicily from 73 to 71, in the quaestio de repetundis in Rome. ${ }^{1}$ Cicero did not have the chance to complete his prosecution, however, since Verres abandoned his defense after the first hearing of the case and went into exile in Massilia. Cicero's success against Verres undoubtedly enhanced his reputation as an orator, and he capitalized upon it by publishing the speech (the Divinatio in Caecilium) that had won him the right to prosecute, his speech from the first hearing, and five speeches he represented as the ones he had given in the second hearing, though it had not taken place.

The speeches purporting to be from the second hearing of Verres' trial are the longest works in the surviving Ciceronian corpus, ${ }^{2}$ and they are valuable sources for many aspects of late republican history and culture. As he describes Verres' alleged crimes as governor in the second, third, fourth, and fifth speeches of this second actio, Cicero also provides a detailed account of many aspects of life in Roman Sicily. ${ }^{3}$ Mostly, and most naturally, scholars have read the speeches from a Roman perspective: as examples of Cicero's development as an orator, and for the insight they provide into the political climate of the late 70s B.c. ${ }^{4}$ When scholars consider the Sicilians who populate the second set of Verrine orations, it is also usually from the perspective of Rome, with an emphasis on their patronage relationships with Roman senators and magistrates. ${ }^{5}$ The

All parenthetical citations in the text and footnotes refer to the second actio of Cicero's In Verrem, unless otherwise noted. Latin texts and English translations are from Greenwood 1928-1935, with my modifications. I am grateful to the editors and anonymous referees for their helpful suggestions and criticisms, and to Ralph J. Hexter for his comments on an early version of this article.

${ }^{1}$ See Marinone 1950 for the chronology of the trial.

${ }^{2}$ Indeed, they were probably his longest works in absolute terms; cf. Tac. Dial. 20: quis quinque in Verrem libros exspectabit? ("Who will sit out the five books against Verres?").

${ }^{3}$ Especially the island's economy under the lex Hieronica: see Soraci 2011 and Genovese 1999; Carcopino 1914 is still influential. The speeches are also key texts for understanding Roman attitudes towards their empire in the closing decades of the republic: see, for example, Lavan 2013; Miles 2008; Steel 2001.

${ }^{4}$ Including Frazel 2009; Butler 2002: 24-84; Vasaly 1993: 104-130, 208-217; Brunt 1980. Scholars have also considered the circumstances of Cicero's composition and circulation of the "fictional" speeches of the second hearing, and the relationship these speeches would have borne to the events of the trial itself (e.g., Gurd 2010).

${ }^{5}$ See, for example, Nicols 2014: 163-205; Prag 2013; Deniaux 2007. On the potentially negative implications of these relationships, see Damon 1997: 206-222.

PHOENIX, VOL. 69 (2015) 3-4. 
identities and the social, political, and economic circumstances of these Sicilians have mostly been neglected. ${ }^{6}$

While Cicero's invective makes it difficult to recover reliable information about the events and individuals mentioned in the speeches, I argue in this article that it is possible to read the Verrines from a non-Romanocentric perspective, concentrating on Sicilian rather than exclusively Roman spheres of activity on the island: namely, local political, economic, and social relations. After all, most of the events portrayed in the Verrines took place in the highly stratified and competitive world of the hellenistic Sicilian polis, which by 70 в.c. had been in contact with the institutional and the human manifestations of Roman imperial power, including Roman magistrates, businessmen, and landowners, for almost two centuries. ${ }^{7}$ I also ask what modern readers can glean from Cicero's speeches about the Sicilians themselves, especially regarding their relations with each other and with outsiders (including the governor himself), in the context of the political, social, and economic life of the polis. I acknowledge, however, that the speeches are in no way straightforward accounts of everyday life in Sicily in the 70s B.c. Cicero clearly sought to persuade his audiences of Verres' guilt by portraying the Sicilian "victims" sympathetically and by casting the personalities and actions of Verres and his Sicilian associates in the most negative light possible. In addition, Cicero does his best to implicate Verres in every instance of corruption and abuse in Sicily that occurred during his governorship.

I propose a reading of the Verrines that resists Cicero's invective, and that instead focuses on what Sicilian individuals and communities hoped to gain from their interactions with the governor and other prominent Romans in the province: not necessarily, and not just, access to Rome and its government. Rather, I argue, the relationships fostered between provincials and Roman administrators could have a more immediate impact in civic contexts, inter alia in resolving local legal disputes and gaining economic advantage. In these contexts, the Roman governor had plenty of opportunities for making and reinforcing friendships as well as enmities, and thus could be a divisive figure. Many of the cases in which Verres intervened during his governorship were intra-polis disputes that were brought to his attention by the Sicilians themselves, and many of the subsequent complaints against Verres were the result of damaged relationships within the province. Thus, by resisting Cicero's portrayal of a Sicily

\footnotetext{
${ }^{6}$ A notable exception is Pittia 2004. Here I use "Sicilians" to refer to native inhabitants of the island, including some Roman citizens (since Cicero often does not indicate their geographic origins), and excluding Roman magistrates and other temporary or periodic inhabitants (e.g., absentee landowners and negotiatores). We should not assume an island-wide, unified Sicilian identity; indeed, as I emphasize below, Cicero's speeches highlight the essentially polis-based framework of individual identity in this period.

${ }^{7}$ For insights into the political and cultural world of the hellenistic Sicilian polis under Rome, see Campagna 2011 and, more broadly, Prag and Quinn 2013.
} 
united and "free of social tensions," ${ }^{8}$ we can detect many groups and individuals with competing interests in Sicily who had much to gain (and to lose) through their interactions with the governor.

At the organizational level, Cicero's division of the speeches of the second hearing according to the categories of Verres' crimes in Sicily — as a purveyor of justice (Book Two), as an administrator of the tithe system (Book Three), ${ }^{9}$ as an art collector (Book Four), and as a commander (Book Five)-make it difficult to gain a coherent sense of the governor's relations with any one community or individual. Cicero would have his audience believe that a few Sicilian cities-or a few malefactors within certain cities-were in league with Verres, while the rest suffered from his crimes.

However, a close reading of the speeches of the second actio reveals that not all of the island's communities supported Cicero's prosecution to the same degree, with some communities offering far more material assistance than others. ${ }^{10}$ Cicero implies that there were sixty-five administrative units (civitates) in Sicily at the time of Verres' governorship, ${ }^{11}$ most of them based in urban centers established centuries earlier by Greek and Phoenician colonists or by hellenizing indigenous groups. He acknowledges that three communities in eastern Sicily were partly, or entirely, in Verres' camp: Messana, Syracuse, and Leontini. He attributes Messana's support for Verres at the trial to its citizens' participation in Verres' crimes and abuses. ${ }^{12}$ Most of his evidence for Verres' activities in Messana comes from Roman negotiatores and aratores and enfranchised Sicilians who seem not to have shared the Mamertines' loyalty to the former governor. ${ }^{13}$ Cicero has a harder time explaining the lack of support from Syracuse and Leontini. He excuses the Syracusan council (boule/senatus) from complicity in Verres' crimes (4.137-151), although, as I show in the next section, he cannot obscure the fact that a significant portion of the city's ruling class had supported Verres' judicial interventions.

\footnotetext{
${ }^{8}$ Scuderi 1996: 423.

${ }^{9}$ Steel 2007.

${ }^{10}$ Such a close reading is, of course, easier for a modern reader (who may consult maps, indexes, and other tools for organizing and visualizing Cicero's text) than it would have been for the initial readership of the Verrines. For opposition to Cicero's prosecution, see Dilke 1980, but focusing only on eastern Sicily. Pittia (2004: 29-30) also touches on the varying levels of opposition to Verres in Sicily. Havas 1969 is a comprehensive but relatively uncritical treatment of Verres' interactions with Sicilian civitates, focusing on the political reasons for Verres' good relations with Messana and Eryx, without considering the diversity of opinion within these and other communities.

${ }^{11}$ Two censores were appointed for each civitas to assess its citizens' property (2.133-137), for a total of 130 censores in Sicily.

${ }^{12}$ For example, at 2.75 and 5.21-23. However, Cicero attempts to exculpate their chief delegate, C. Heius, whom he appears to have turned into a hostile witness to Verres during the trial in Rome (4.3-18).

${ }^{13}$ These Roman citizens include C. Numitorius, the Cottii, and Q. Lucceius, who testified about the execution of P. Gavius (5.163-165); and Cicero's hosts Cn. Pompeius Basiliscus and the Pompeii Percenii (4.25).
} 
Less explicit is the lack of support Cicero may have received from other prominent communities. For example, Cicero mentions only one incident during Verres' governorship that took place in Tauromenium, a civitas foederata on the northeastern coast $(2.160,3.13)$, and there is no indication that the community sent an official delegation to Rome in support of the prosecution. ${ }^{14}$ This absence cannot be attributed to the city's obscurity (after all, Cicero repeatedly cites the favorable terms of its treaty with Rome) or to any logistical difficulties Cicero may have encountered in Sicily. Tauromenium lies on the coastal route that connected the major urban centers of the eastern coast (Messana, Catina, and Syracuse), so it is unlikely that Cicero lacked an opportunity to visit the city and gather evidence. ${ }^{15}$

Cicero also appears to have lacked substantial support from three prominent communities in the western half of the island: Panhormus, Thermae, and Lilybaeum. Although Panhormus sent official representatives to Rome (2.120), Cicero does not mention the names of these legati or describe their testimony. Thermae Himeraeae, despite being the home city of Sthenius, the wealthy and prominent Sicilian who initiated the case against Verres (discussed in the next section), appears not to have sent an official delegation to Rome. Similarly, there is no indication that Lilybaeum sent representatives to Rome to support the prosecution, though Cicero had been stationed there as a quaestor a few years earlier and had visited the city on his evidence-gathering trip. Cicero masks this lack of support in part by characterizing his account of events as the "universally accepted" version. For example, he claims that "all Lilybaeum saw" and "all Sicily heard" Verres' flogging of the Roman citizen C. Servilius in the forum (5.140: nemo Lilybaei fuit quin viderit, nemo in Sicilia quin audierit), though he appears to be relying on private witnesses from Lilybaeum for his account. ${ }^{16}$

On the other hand, the strongest opposition to Verres appears to have been concentrated in northern and north-central Sicily, especially in the coastal and inland areas just west of Mount Etna (e.g., in Tyndaris, Halaesa, Centuripae, and Agyrium). Cicero may have given prominence to witnesses from Tyndaris, Halaesa, Centuripae, and Segesta because of these communities' close historical

\footnotetext{
${ }^{14}$ Cicero says only that the people of Tauromenium have taken down the statue of Verres in their forum (2.160), without mentioning the specific abuses that may have provoked such an action, or when it occurred (i.e., before or after similar actions in other cities). He mentions no witnesses from the city itself, though he cites the testimony of the aratores M. and P. Cottius, ex agro Tauromenitano ("from the Tauromenium district," 5.165).

${ }^{15}$ Cicero made visits to Syracuse and Messana, as well as to Leontini, Aetna, and Centuripae, inland cities that were a short distance from this coastal route (Marinone 1950: 41; Prag 2007a: 270).

${ }^{16}$ Cicero's main sources of information for events in Lilybaeum are his amicus and hospes Pamphilus (4.32) and Diodorus of Melita, who resided in the city (4.38-42), as well as unnamed members of the city's Roman conventus (5.11).
} 
links with Rome and the Italian peninsula. ${ }^{17}$ Presumably their leading citizens would have been sufficiently proficient in Latin to make a favorable impression on a Roman jury as witnesses.

However, not all of the discrepancies in communities' prominence in $\mathrm{Ci}^{-}$ cero's speeches can be explained by social and cultural differences: it is unlikely that Sthenius was the only wealthy and influential notable that Thermae could produce, or that Lilybaeum, with its long history as a trade hub and Roman administrative center, could not muster proficient Latin speakers to represent it in a Roman court. ${ }^{18}$ Instead, we must allow that the civic bodies of several Sicilian cities were not uniformly united against Verres, a reality that Cicero does his best to obscure but that he must acknowledge in some cases (for example, in Syracuse and Leontini).

One source of disunity among the communities of Sicily would have been their different economic and juridical status in relation to Rome. ${ }^{19} \mathrm{We}$ can follow Cicero in making a distinction between "privileged" and "unprivileged" communities, especially in relation to the assessment and collection of Sicily's annual grain tithe. Privileged communities include civitates whose lands were exempt from the tithe (Halaesa, Centuripae, Segesta, Halicyae, and Panhormus), all of which (except perhaps Panhormus) strongly opposed Verres, probably because their ruling classes had the most to lose from abuses of the tithe system. ${ }^{20}$ Cicero also mentions communities with special arrangements regarding the assessment and collection of the tithe (the "treaty states" of Tauromenium, Netum, and Messana), or with other special relationships with Rome (including Tyndaris, one of the "seventeen loyal cities of Sicily"), that did not show consistent opposition to Verres as a group. The two centers of Roman administration in Sicily, Syracuse in the east and Lilybaeum in the west, are notable for their failure to send official delegations to Verres' trial in Rome, though clearly there was some opposition to the governor within them. While Syracuse was the seat of the governor and his staff, Lilybaeum hosted one of the island's two quaestors. ${ }^{21}$ These cities therefore had a special interest in maintaining good relationships with Roman magistrates (most immediately, Verres' successor and alleged sup-

\footnotetext{
${ }^{17}$ Tyndaris was one of the "seventeen loyal states of Sicily," while Segesta shared cognatio with Rome (5.125). Centuripae, Halaesa, Segesta, and Halicyae were immunes civitates ac liberae ("free communities exempt from taxation," 3.13).

${ }^{18}$ Cicero asserts that Verres' former quaestor Q. Caecilius Niger, his rival for the right to prosecute Verres, received his education in Greek and Latin at Lilybaeum and Syracuse respectively (Div. Caec. 39), implying that this training was not adequate for the rhetorical rigors of a Roman court.

${ }^{19}$ On the status of Sicilian cities, see, in detail, Genovese 1993.

${ }^{20}$ Cicero mentions Panhormus as one of the civitates immunes at 3.13 , but not at 2.165 , perhaps reflecting the lack of strong opposition to Verres among the Panhormitan aratores.

${ }^{21}$ Although Cicero himself provides the earliest evidence of the assignment of two quaestors to Sicily (and of these quaestors' spheres of activity on the island), this practice probably originated in the Second Punic War; Prag (2014) provides an overview of the development of the quaestorship.
} 
porter L. Metellus), so it is not surprising that they were lukewarm towards the prosecution of Verres.

By the time of Verres' governorship, the patchwork nature of relationships between Sicilian civitates and Rome-in which the tithe-free land of one civitas could border the tithable land of another civitas, or even abut Roman ager publicus - had led to a situation in which individual Sicilians, particularly from privileged communities, owned or leased land outside their home community, creating conflicts of interest within both their home and their host communities. This is particularly true of Centuripae, whose citizens were prominent as renters of the land of other Sicilian communities, including Aetna and Leontini. The Centuripean aratores who had holdings in other communities formed a faction strongly opposed to Verres, even sending their own representatives to the trial in Rome in addition to the official representative sent by the boule (3.108): apparently the aratores had particular complaints that did not apply to the entire civic body. On the other hand, Cicero admits that the citizens of Leontinimost of whom did not farm the city's territory, the bulk of which was rented to outsiders like the Centuripean aratores - were not helpful to his prosecution because they had not been affected by Verres' abuses of the tithe (3.109).

We can also distinguish (though Cicero does not) between communities reliant mainly on agriculture, and cities with more diverse economies. For example, four of the eight port cities in which Cicero accuses Verres of dodging export taxes-Syracuse, Lilybaeum, Panhormus, and Messana (in addition to Agrigentum, Thermae, Halaesa, and Catina, 2.185) - are absent from Book Three's narrative of Verres' abuses of the tithe system. Even if their leading citizens were landowners, these communities as a whole probably felt less pressure from Verres' tithe exactions than the areas that Cicero singles out as agri deserti, all of which lay in the east-central interior (Herbita, Henna, Murgentia, Assorus, Imachara, and Agyrium, and the lands around Mt Etna and Leontini, 3.47), and for some of which he cites reductions in the number of aratores during Verres' governorship (Leontini, Herbita, Agyrium, and Mutyca, 3.120-122).

The case of Centuripae, whose aratores appear to have identified themselves as a distinct group in need of their own representatives in the prosecution of Verres, hints at the intra-community rifts (even in communities that Cicero presents as wholeheartedly in opposition to Verres) that could exist alongside inter-community divisions. The remainder of this article explores the impact these intra-community rivalries had on relations between administrators and provincials in Sicily. The next section explores some of the circumstances in which differences of opinion could arise in Sicilian communities-namely, in the resolution of legal disputes - and examines how Cicero obscures or downplays factionalism within communities in order to portray Verres as the sole instigator of abuses in the provincial legal system. Section III shows how the grain tithe could create intra-community friction by pitting local notables against the collectors who represented the interests of the Roman state. 
I restrict this study to Books Two and Three for the sake of concision, and because they treat the spheres of activity in which the greatest number of individuals came into contact with Roman magistrates with the greatest regularity: the administration of justice and the grain tithe. However, as my conclusion shows, these activities cannot be extricated from other spheres of interaction between administrators and the communities under their jurisdiction, including military exercises (Book Five), "culture" (Book Four), and extra-provincial politics. In the cases analyzed in the next two sections, I am not concerned with Verres' culpability for its own sake; rather, I emphasize the ways in which Cicero's portrayal of Verres obscures the essentially reactive nature of his involvement in conflicts that were primarily local in scope and impact.

\section{COLLABORATION AND CONFLICT IN LEGAL AFFAIRS (BOOK TWO)}

Before examining specific incidents from Book Two (usually titled De praetura Siciliensi), it is necessary to demonstrate how collaboration and conflict between the governor and Sicilians were rooted in the world of the polis. Cicero emphasizes the importance of local notables (principes civitatis) in Sicilian civic life, inter alia as the chief negotiators of their communities' relationship with the governor and other representatives of Rome, including Cicero himself, on his evidence-collecting trip in the spring of 70 в.c. ${ }^{22}$ The archaeological and epigraphic record for the first half of the first century в.с., in which we see monumental building projects underway in several cities accompanied by a lively culture of public commemoration, lends verisimilitude to Cicero's account. ${ }^{23}$ There is also plentiful evidence in the Verrines, and in the archaeological and epigraphic record, of the "Roman diaspora" in Sicily: resident Roman citizens usually characterized as aratores and/or negotiatores, many of whom appear to be of Italian origin, who participate in local political, economic, and social life as members of a Roman conventus. ${ }^{24}$

In peaceful periods of the republican era the Roman senate staffed overseas provinces with only a handful of magistrates. In the case of Sicily, the governor was accompanied by two quaestores, a number of senatorial legati, and other comites of equestrian or senatorial rank. This administrative "inner circle" was assisted by a similarly small number of official apparitores (including scribes, couriers, criers, and lictors), probably no more than a few dozen individuals in total, amongst whom there was considerable annual turnover. ${ }^{25}$ Therefore, the governor needed to cultivate the local ruling classes of his province as sources

\footnotetext{
${ }^{22}$ Rizzo (1980) points out that these principes were not necessarily magistrates.

${ }^{23}$ For recent surveys of the archaeology and epigraphy of Roman republican Sicily, see Campagna 2011; Prag 2007a; Wilson 2000.

${ }^{24}$ For textual evidence of this diaspora, see Frank 1935.

${ }^{25}$ See Pittia 2007 and Classen 1980 for the composition of Verres's staff.
} 
of reliable information and assistance in order to do his job effectively, let alone to profit from it.

Most urgently, the Roman administration's ability to police and defend the province relied on the cooperation and participation of communities, since Roman legions were stationed in Sicily only in times of extraordinary disruption, such as the slave revolts of the late second century в.c. Implicit in Cicero's narrative of Verres' crimes against the Sicilian navarchi (5.80-125) is the Roman governor's reliance on contributions by the Sicilian socii of ships, supplies, and manpower for the maritime defense of the province, with each ship under the command of a captain appointed by his community, and the fleet usually under the overall command of a Roman magistrate. ${ }^{26}$ Unsurprisingly, the prosecuted captains named by Cicero came from the leading ranks of their communities: for example, both Aristeus of Tyndaris and his father, Dexo, who came to court in Syracuse to plead for his son's life (and later attended the trial of Verres in Rome), had been hospites of the governor $(5.108-109,128)$.

Though Cicero attempts to portray Verres as the guiding force behind Roman administrative abuses in Sicily, in reality the small scale of Roman provincial administration and its reliance on local assistance made it difficult for the governor and his immediate circle to be interventionist. Even outside the military sphere, the governor's interactions with the Sicilian principes and other socially and economically prominent individuals (such as Roman negotiatores and aratores), which often came about at the behest of the principes themselves, were filled with both opportunity and peril. ${ }^{27}$ Books Two and Three illustrate how collaborative relationships between the governor and provincials in the spheres of jurisdiction and tax collection, respectively, could go awry both in ordinary circumstances and under the special conditions of Verres' governorship.

In Book Two, Cicero recounts several local disputes about inheritances, magistracies, and priesthoods in which Verres intervenes, in many cases on the advice of Sicilians and not on his own initiative, and in almost all cases with local assistance. Cicero states that the procedures to be followed in civil cases in Sicily - and the Roman governor's role in them-are clearly defined by the lex Rupilia enacted by the proconsul P. Rupilius six decades earlier (2.32-34). According to Cicero's summary, the lex Rupilia left many types of civil cases involving Sicilians to be resolved by Sicilians themselves, including cases between two citizens of the same city, between two Sicilians of different cities, and between an individual and a community.

However, the lex Rupilia made no explicit provisions for many types of cases (for example, between a Sicilian and a non-Roman "foreigner"). ${ }^{28}$ Additionally,

\footnotetext{
${ }^{26}$ See Prag 2007b for the role of Sicilian communities in the defense and policing of the province.

${ }^{27}$ Cicero later emphasized the potential danger that the activities of a Roman governor's provincial associates posed to his reputation in a letter of 60 B.c. to his brother Quintus, who was then serving as governor of Asia: see Q. fr. 1.1, discussed by Damon (1997: 206-207).

${ }^{28}$ Kantor 2010.
} 
the lex Rupilia appears to have allowed the governor to play a role in certain phases of cases, for example, by nominating a third-party city council (senatus ex aliqua civitate) to try a case between an individual (privatus) and a community (populus, 2.32). Through the edicts Verres issued to combat the malfeasance of individual judges (2.33) and city councils (2.34), he also opened himself up to appeals from alleged victims of local judicial corruption. Furthermore, the complexity and fluidity of Sicilian jurisprudence, in which local and Roman procedures coexisted, and were perhaps even applied in the same cases, meant that Cicero could exploit his audience's lack of knowledge of its finer points in order to present Verres' interventions in the worst light possible, even if they had been exercised within the limits of his imperium and consistently with local and/or Roman practice. ${ }^{29}$

The two inheritance cases (petitiones hereditatis) that Cicero describes in detail-those of Heraclius of Syracuse (2.35-50) and Epicrates of Bidis (2.55-63) - came to Verres' attention through local informants who (Cicero alleges) hoped to gain advantage from the governor's intervention. Heraclius and Epicrates were wealthy and well-connected native Sicilians who had received sizeable legacies that stirred up envy within their communities. Verres learned of Heraclius' circumstances, according to Cicero, from the Syracusans Cleomenes and Aeschrio, who appear as collaborators with the governor in other instances. Since Heraclius was required by the will to set up statues in the palaestra of Syracuse, Cleomenes and Aeschrio received further assistance in their suit from unnamed Syracusan magistrates (palaestritae) who claimed that the statues had not been erected, and therefore that the estate should be forfeited to the palaestra (2.36-37). Verres only became directly involved in the proceedings against Heraclius at the sortitio dicarum stage, when (in accordance with the Rupilian law) he oversaw the selection of juries for the cases on the docket at Syracuse (2.37).

Verres' culpability in the legal procedures that followed is questionable. Cicero asserts that Heraclius preferred to be tried by his fellow citizens (even though they stood to benefit from his conviction), in accordance with the provisions of the lex Rupilia for a case between citizens of the same community (2.38). Heraclius apparently hoped to avoid the governor's intervention, with the collusion of his opponents, by having the judges chosen by lot. Heraclius' opponents instead requested that the judges be selected, at Verres' discretion, from other civitates in the district, a procedure not included in $\mathrm{Ci}^{-}$ cero's summary of the lex Rupilia. Cicero claims that, in the end, Verres appointed the five judges for the case himself (2.39). Regardless of Verres' reasons for coming to this decision, the different methods of selecting judges advocated by Heraclius and his opponents hint at the governor's considerable latitude in defining juridical procedures even in cases between Sicil-

${ }^{29}$ Fournier 2010a; Maganzani 2007. 
ians, as well as his receptivity to advice from the Sicilians themselves in doing so.

After the judgment against Heraclius, in which Cicero admits that the citizenry of Syracuse colluded (2.45), Cicero decries the subsequent auctioning off of Heraclius' property - which he presents as Verres' quid pro quo for allowing the Syracusans to keep Heraclius' estate ${ }^{30}$ — as one of many crimes against the entire Syracusan community (scelera ... invitissima civitate). Cicero claims that the auction occurred against the wishes of the council and the citizen body (invito populo senatuque Syracusano, 2.50). However, he must acknowledge that the estate had indeed been forfeited to the palaestra and thereby to the community as a whole (2.45). The Syracusans' subsequent objections to the auctioning off of Heraclius' property are spurred by the large sum extorted by Verres rather than by the auction itself $(2.47-50)$.

In bringing the episode to a conclusion, Cicero complains that many individual Syracusans benefited from the confiscation of Heraclius' inheritance (quod praeda ex illis bonis ad multos Syracusanos ... venerat, 2.50) and goes on to name two other Syracusans besides Cleomenes and Aeschrio, Theomnastus and Dionysodorus, who helped Verres carry out his "thefts" from the city (illa scelera per Theomnastum et Aeschrionem et Dionysodorum et Cleomenem invitissima civitate illa facta sunt). By calling out these four individuals, Cicero separates them from the population of Syracuse as a whole, and shifts his audience's attention to the crimes Verres allegedly committed against the Syracusan civic body (the theft of artworks he goes on to discuss in Book Four ${ }^{31}$ and away from the complicity of the Syracusans in the proceedings against Heraclius.

In the case of Epicrates of Bidis, too, Cicero expends considerable rhetorical effort to implicate Verres in a dispute essentially between a Sicilian individual and his community. As in the case of Heraclius, Cicero claims that Verres learned of Epicrates' inheritance from unnamed inimici of the leading man of Bidis (bic longeprimus civitatis), who sent word to the governor through unnamed go-betweens (per eius interpretes, 2.55). Again, the palaestritae of Bidis were the plaintiffs in the lawsuit brought against Epicrates. Despite Cicero's effort to place Verres at the center of the ensuing events by connecting him to the eques Volcatius, whom the palaestritae allegedly bribed in order to ensure a favorable judgment, the governor only takes direct action relatively late in the narrative, after the plaintiffs have pursued Epicrates to Rhegium to demand repayment of their bribe (2.55). ${ }^{32}$

${ }^{30}$ Though this was standard Roman procedure (missio in possessionem; Maganzani 2007: 140).

${ }^{31}$ 2.50: ut urbs tota spoliaretur ... ut omnia signa iste per eos homines quos nominavi . . auferret ("the whole city was stripped of its treasures ... with the help of the persons whom I have named, [Verres] carried off every statue").

${ }^{32}$ See Damon 1997: 207-211 for Cicero's depiction of Volcatius, whose collusion with Verres had already been alleged in the inheritance case of Sosippus and Philocrates of Agyrium (2.25-27). 
Cicero obscures the exact manner in which Verres became openly involved in the case, claiming that the plaintiffs headed to Syracuse from Rhegium, where their complaints became well known. ${ }^{33}$ Cicero then admits that Verres simply ordered Volcatius to repay the money he had received from the Bidini; Verres' wrong-doing, claims Cicero, is apparent from the fact that he failed to punish Volcatius or to remove him from his circle of friends (2.58). Furthermore, as Cicero seeks to condemn Verres' failure to punish the Bidini and to insinuate that Verres somehow profited from the case, he makes clear that the people of Bidis put up no opposition to the case against Epicrates at any point, and ended up as the recipients both of the contested inheritance and of Epicrates' own property once he had abandoned his case and fled to Rome $(2.59-61) .{ }^{34}$

In the other legal cases narrated in Book Two, it is clear that Verres intervened in local disputes, gaining both friends and enemies in the process; it is less clear that these interventions constituted "abuses of power." According to Cicero, Heraclius of Centuripae testified that when a fellow citizen brought a "false claim" (per calumniam malitiamque) against him, Verres not only increased the amount of the claim, but also inappropriately annulled the local arbiter's judgment in Heraclius' favor (2.66-67). However, in accordance with his own edict (quoted at 2.33), Verres may in fact have been attempting to combat local judicial corruption by nullifying a judgment in which the arbiter had colluded with Heraclius. Verres' judicial "crimes" against Sopater of Halicyae - which Cicero discusses at length (2.68-75) - also had their origins in personal rivalries, and were not initiated by Verres himself: Sopater's inimici had prosecuted him unsuccessfully in the praetorship of Verres' predecessor C. Sacerdos, and brought the same (capital) charges under Verres (2.68). ${ }^{35}$

In these cases, it is difficult to assess the propriety of Verres' actions, since we possess only Cicero's arguments against the former governor. Cicero's strategies for presenting legal cases involving Sicilians in the best possible light for his overall case are apparent in his narrative of Verres' first "crime" in the province: the extortion of a payment from Dio of Halaesa in order to prevent the forfeiture of an inheritance that Dio's son had received from a relative, Apollodorus Laphiro, to the sanctuary of Venus at Eryx (2.19-24). Cicero immediately states that Dio is "now" (i.e., at the time of the trial) a Roman citizen, thanks to Q. Metel-

Maganzani (2007: 141) points out that Epicrates fled at a relatively early stage of the case, before the dica (announcement of the case) and before the first meeting of the parties at the conventus.

${ }^{33}$ 2.56: Res percrebuit et in ore atque sermone omnium coepit esse ("the story spread, and began to be mentioned and discussed everywhere").

${ }^{34}$ Indeed, the people of Bidis actively claimed the legacy: adeunt Bidini, petunt hereditatem (2.59).

${ }^{35}$ See Fournier 2010a: 161-162 for the case of Sopater, and for the procedural differences between capital cases and other types of litigation. 
lus (2.20). ${ }^{36}$ Dio's Roman citizenship affirms his high social standing; it also confuses his legal standing in what follows. Cicero presents the case in Roman terms-for example, Dio's son (whose name and age are omitted) is assumed to be under his father's potestas - though the dispute essentially concerns a legacy from a native Sicilian to a relative who was probably not a Roman citizen at the time of the bequest.

Verres is cast in an active role in the incident, pursuing Dio and his wealth as soon as he got off the boat in Messana. However, in order to act so quickly, Cicero acknowledges that Verres was informed of Dio's circumstances before he left Italy (ad urbem cum esset, audivit Dioni cuidam Siculo permagnam venisse hereditatem, 2.21). Although Cicero does not identify Verres' informant, it may have been P. Naevius Turpio, who went on to contest against Dio in court on behalf of the sanctuary of Venus of Eryx. Cicero describes Turpio as a criminal and a stooge of the governor, ${ }^{37}$ and says nothing of his origins or occupation. In a more neutral interpretation, Turpio was a Roman eques with a wide sphere of activity in Sicily who possessed the social and economic wherewithal to become an early and consistent member of Verres' cohors: in addition to representing Venus of Eryx in the trial of Dio of Halaesa, Turpio was decumanus for two communities in the western Sicilian interior, Petra and Halicyae (3.90-91), and served as prosecutor of the navarchi in Syracuse (5.108). ${ }^{38}$ Additionally, although Cicero claims that if the procedure against Dio had been legitimate, the quaestor whose "sphere" included Eryx (2.22: is qui Erycum montem obtinebat; cf. 2.25) would have contested the legacy, it is not clear prima facie why this magistrate should be involved in an inheritance dispute between a native Sicilian and a Sicilian temple, especially if that magistrate was based in western Sicily (in Lilybaeum) and the trial took place before the governor in Syracuse.

Cicero does not devote the same amount of detail to the case of Dio of Halaesa as he does to the later cases of Heraclius and Epicrates, but his narrative introduces themes that recur throughout Book Two (and the entirety of the second actio): Verres' deliberate targeting of wealthy and prominent Sicilians, his dependence on disreputable individuals in Sicily (both provincials and Roman equites like Turpio and Volcatius), his disregard for the precedents set by earlier governors (Dio's inheritance had gone unchallenged in the praetorship of Verres' predecessor, C. Sacerdos), and his inordinate fondness for Venus and collusion with her sanctuary at Eryx. Whatever the true circumstances of the cases of

\footnotetext{
${ }^{36}$ Hic est Dio, iudices, nunc beneficio Q. Metelli civis Romanus factus. Cicero later reveals that Dio took Quintus Caecilius as his praenomen and nomen (2.23). Dio's benefactor is usually identified as Q. Caecilius Metellus Creticus, consul designate for 69 в.c. and, along with other Metelli, a supporter of Verres at the trial (1.26).

${ }^{37} 2.22$ : istius excursor et emissarius, homo omnium ex illo conventu quadruplatorum deterrimus ("[Verres'] agent and emissary, the most worthless of all the informers in that district").

${ }^{38}$ Della Corte (1990: 65) hypothesizes that he was from the Eryx district, or perhaps from Lilybaeum.
} 
Heraclius of Syracuse, Epicrates of Bidis, Dio of Halaesa, and other Sicilian principes, Cicero would have it appear that Verres intervened illegally, for his own advantage, and to the detriment of men of distinguished character and reputation.

However, given how little is known (beyond the details Cicero provides) of the operation of the lex Rupilia, it is possible that the "abuses" of the judicial system that Cicero describes, especially in the appointment of judges (iudicis datio), were well within the governor's prerogative. ${ }^{39}$ Moreover, the details that Cicero chooses to divulge about each case make clear that Verres acted with the support of some (if not most) of the members of these men's communities, though he ended up making formidable enemies in the men adversely affected by his actions. Despite the fact that they had been "deprived of all they had" (expulsi bonis omnibus), Heraclius of Syracuse and Epicrates of Bidis managed to survive in Rome for the remaining two years of Verres' governorship, and they returned to Sicily under the protection of Verres' successor, L. Metellus, who annulled the judgments against them $(2.62-63) .{ }^{40}$ Dio of Halaesa also maintained connections to prominent Roman politicians, including, claims Cicero, Verres' own advocate Hortensius (2.24). ${ }^{41}$

The most notable case of such an enmity arising from the governor's intervention in local affairs is that of Sthenius of Thermae, the Sicilian who helped to initiate the prosecution of Verres in Rome (2.82-118). Sthenius began as a hospes of Verres and as a potential source of information and assistance to him (2.82), as he had been to previous generations of Roman magistrates in Sicily, including Marius and Pompey $(2.110,113)$. After Verres broke off their hospitium when Sthenius refused to assist him in acquiring Thermae's public statues, the governor turned to Sthenius' inimicissimi in Thermae, Agathinus and Dorotheus, for hospitality and for assistance in bringing charges against Sthenius (2.89). Like Heraclius and Epicrates, Sthenius had the means to flee Sicily before his trial started, and sought refuge with friends in Rome $(2.91,95)$.

Cicero is silent about the origins of the local enmities that played a prominent role in the cases of Sthenius and other politically, socially, and economically prominent Sicilians. ${ }^{42}$ We can assume that many were rooted in rivalries over magistracies, priesthoods, and other signifiers of status in the world of the polis.

\footnotetext{
${ }^{39}$ Fournier 2010a: 173-175.

${ }^{40}$ The fact that Epicrates initially fled to Rhegium and stayed there for some time indicates that he had friends, and perhaps also property, in that city (2.55-56).

${ }^{41}$ Cicero also mentions here that M. Lucullus, proconsul of Macedonia in 72 в.c., and Servilia, widow of Q. Lutatius Catulus and Hortensius' mother-in-law, had ties of hospitality (hospitium) with Dio.

${ }^{42}$ Though Sthenius seems to have been a target for local rivals also in the previous decade, since his inimici denounced him to Pompey for his previous familiaritas and hospitium with Marius (2.113). According to Fournier (2010b: 559), the cases of Sthenius and Sopater suggest that one
} 
In outlining the other ways in which Verres allegedly abused his powers as governor, Cicero describes many arenas in which rivalries between individual principes could play out. Competition over admission to city councils could be intense and controversial, especially in cities like Agrigentum and Heraclea, where council seats were divided between "old" and "new" citizens (2.123-125). ${ }^{43}$ According to Cicero, even elections for priesthoods, which offered their holders few obvious opportunities for profit, were competitive. Artemo Climachias, a leading citizen of Cephaloedium, allegedly bribed Verres to ensure that he would obtain the high priesthood of that city over his opponent Herodotus, who had stronger qualifications and greater local support (2.128). Cicero claims, rather implausibly, that Verres ensured the election of Climachias by altering the civic calendar, moving up the date of the election so that Herodotus, who was in Rome at the time, would not be present to contest it (2.129-130). ${ }^{44}$

Cicero singles out the censorship as the local magistracy that attracted the greatest competition because of the high authority it confers (2.131: propter magnitudinem potestas hic magistratus a populo summa ambitione contenditur), and he devotes considerable space to Verres' abuse of the appointment system. Verres had identified the existing system, in which the censors were chosen by, and within, their respective communities, as a source of local corruption (correctly, Cicero admits), and therefore transferred the appointment of censors to his own authority, and to Syracuse (2.132-133). Verres, however, had little direct involvement in making the appointments; Cicero's allegations instead revolve around the character of Timarchides, a libertus to whom Verres delegated responsibility, and who was particularly skilled, according to Cicero, in sniffing out existing economic and political rivalries within the province (2.134-136; esp. 2.135).

Verres' system of appointment does not appear to have attracted strong opposition among the wealthiest Sicilians, since the censorship was now divorced from local political machinations, and instead went (writes Cicero) to the highest bidder. ${ }^{45}$ The men who gained censorships naturally used them to their own advantage, to reduce their own burdens and to increase the burdens of others in their community (2.138). Such a development would ultimately have been detrimental to Roman state interests (namely, to extract the largest lawful

strategy used by Sicilian principes for weakening their local rivals was to make multiple accusations to successive governors until they obtained a conviction.

${ }^{43}$ Gabba (1959) discusses the arrangements for the selection of council members in these cities; see also, recently, Covino 2013.

${ }^{44}$ It is more plausible that Climachias and his supporters, who had better knowledge of the civic calendar and electoral cycle of Cephaloedium, devised these "intercalations." Indeed, Cicero goes so far as to admit that it was in concession to Climachias' sensibilities that Verres developed such an uncharacteristically elaborate plan (2.128).

${ }^{45}$ The censors went so far as to commission a statue of Verres, though Cicero claims that they were forced to do so (2.137). 
amount of grain from each community), leading Verres' successor L. Metellus to revert to the latest assessment made prior to Verres' governorship, and to appoint new censors (2.139).

Whatever Verres' intentions and culpability regarding the censorship were, as Cicero makes clear, the peculiar taxation situation of Sicily meant that its civitates were more involved than other provincial communities in the assessment and collection of tax grain, since each censor made the property valuations that determined farmers' tithe responsibilities. ${ }^{46}$ Furthermore, under the lex Hieron$i c a$, the contracts for collecting the annual grain tithe (decumae) were auctioned in Sicily, ${ }^{47}$ by the governor himself, to individual collectors (decumani) who could be Roman, Italian, or Sicilian, necessitating close coordination between communities, the governor, and his representatives. The conflicts that could arise from these interactions - in which the economic well-being of individuals, their communities, and the Roman state itself were often at odds-are the subject of the next section.

\section{THE ROLE OF SICILIANS IN THE GRAIN TITHE (BOOK THREE)}

In Sicily, where contracts for tithe collection were auctioned locally (in Syracuse) and where locals could bid, those most likely to profit from tax-contracts were local elites. Additionally, under the terms of the Lex Hieronica, which protected farmers against the extraction of more than ten per cent of their grain, it was in everyone's interest-except the Roman authorities'-to keep bids as low as possible, thereby encouraging local collusion and price-fixing. ${ }^{48}$ In these normal circumstances, there was already potential for disputes to arise between the governor, the decumani, and the taxed communities; and within communities, between rival bidders for tithes, and between decumani and farmers (aratores) who were members of the same civitas. Verres' efforts to raise the bids for tithes (and hence, in theory, the amount of grain owed to Rome) would only have served to increase these tensions. ${ }^{49}$

In order to bolster his case against Verres, Cicero presents the decumani in general, and Q. Apronius especially, as members of the governor's "inner

\footnotetext{
${ }^{46}$ 2.131: Ille enim est magistratus apud Siculos qui diligentissime mandatur a populo propter hanc causam, quod omnes Siculi ex censu quotannis tributa conferunt, in censu habendo potestas omnis aestimationis habendae summaeque faciendae censori permittitur ("The censorship is, of all magistracies, the one which in Sicily the citizenry is most careful in delegating, because all Sicilians pay their annual tribute in proportion to their assessed wealth, and in making the assessment the censor is entrusted with complete power to value each property and fix the amount due").

${ }^{47}$ Rather than being auctioned off in Rome, by the censors, to societates of publicani, as were most other taxes (including, it seems, the Sicilian portoria and grazing taxes). See Prag 2003: 127-129.

${ }^{48}$ Prag 2003. The lower the bid, the greater the "profit" (i.e., the difference between the amount turned over to the Roman authorities and the amount of grain actually collected) for the decumanus.

${ }^{49}$ 3.40: "Magno," inquit, "decumas vendidi." The higher the bid, the lower the profit for the decumanus. In order to make up his profit, he would have to extort amounts above the limit set by the lex Hieronica, as Cicero claims occurred with Verres' collusion (Prag 2003).
} 
circle," although in reality they were contractors with no official links (beyond the terms of their contracts) to the Roman state ${ }^{50}$ Furthermore, although Sicilians could bid for the tithes of their own communities, either individually or on behalf of the city council, Cicero presents no cases concerning successful bids of this kind. Presumably, when successful, this practice either did not provoke complaint (since the decumanus would be acting in the interest of his city's government), or it would cast Sicilians in an unsympathetic light by showing them extorting their own communities and fellow citizens. Yet there are hints that some of the cases Cicero presents are more indicative of disagreements between individual communities and decumani than of Verres' direct malfeasance. One indication of such cases is that Cicero does not denigrate the decumanus concerned as a "favorite" of Verres, like Apronius and the Syracusans Aeschrio and Theomnastus; or as a "Venerius," one of the slaves of the sanctuary at Eryx, whom Verres allegedly employed as decumani and in other administrative roles.

Cicero presents the case of Amestratus as one of straightforward extortion, in which the town's representatives at the tithe-auction were forced to pay a "bonus" to each successful decumanus - in cash for the first two years of Verres' governorship, in kind in the third year-in order to take over the collection of tithes (3.88-89). In order to counter Verres' claim that the payment was voluntary (as in the case of Thermae, discussed below) Cicero asserts that the representatives had not been instructed by their council to bid for the tithes on behalf of the city, and cites the testimony of one of the representatives, Heraclius, as well as the town's own records. However, this assertion provokes the question of what other purpose the representatives had in coming all the way to Syracuse for the auction: did they anticipate being "forced" to buy their own tithes? The first two decumani for Amestratus, M. Caesius and S. Vennonius, appear to be Roman citizens, and Cicero draws no explicit links between them and Verres; instead, he disparages Bariobalis, the "Venerius" who bought the tithes in Verres' third year as governor. ${ }^{51}$ In recounting Cn. Sergius' treatment of the town of Hybla, Cicero is even more opaque about the identity of the decumanus, who also appears to be a Roman citizen (3.102). He makes no reference to Sergius' connection to Verres, or to Verres' direct intervention in the tithe collection, instead citing as evidence the settlements (pactiones) that the town made with Sergius.

The case of Thermae more explicitly centers around voluntary negotiation between a town and a decumanus: the Thermitans collectively wished to buy the tithe rights to their own territory, hoping (claims Cicero) to avoid extortion

\footnotetext{
${ }^{50}$ See especially Pittia 2007 and Damon 1997: 212-221 for Cicero's portrayal of Apronius' relationship with Verres.

${ }^{51}$ Genovese 1999: 32-33, 40-43. Cicero latches onto Bariobalis' exotic (presumably Punic) name (3.89): cognoscite nomina publicanorum! ("Note the name of these tax-farmer!!"). M. Caesius appears again in the third year of Verres' governorship as the decumanus for Calacte, which is required, at Verres' order, to deliver its tithes at Amestratus (3.101; Genovese 1999: 65-66).
} 
by an agent of Verres, even if they had to bid a high price (3.99). After the Thermitan representatives at the auction were outbid by a certain Venuleiuswho Cicero implies was supported by Verres, though he does not detail their relationship-with the approval of the city council, they offered the decumanus a payment of wheat and cash to forgo his right to collect the tithe. ${ }^{52}$ Cicero does not claim that the Thermitans were forced to make this offer to Venuleius: apparently, they considered it more desirable to pay the successful bidder up front and avoid the possibility of extortion later, during the actual collection of the tithe. Cicero provides the town records of Thermae, as well as the testimony of Posidorus, one of the representatives, as evidence that the payment was offered and accepted.

In all of these cases, it is difficult to determine whether Verres was responsible directly (through active collusion) or indirectly (through failure of effective monitoring) for the malfeasance of individual decumani. However, it is telling that "abuse" of the tithe system in Sicily extended to men whose status as Roman citizens exempted them from the kind of ad hominem attacks that Cicero could aim at tax-collectors of lower rank, such as freedmen and public slaves. It is also significant that these decumani (and many of the other collectors Cicero discusses, including Q. Apronius) were non-locals, and perhaps even non-Sicilians, who challenged the prerogatives of Sicilian towns (or individuals or groups within them) to bid for the right to collect their own tithes. The results of these contests were unfavorable to the towns, and to their leading citizens-men like Heraclius of Amestratus and Posidorus of Thermae. They therefore contributed to communal and individual dissatisfaction with the governor, who had ultimate authority over grain tax assessment and collection, even if he had little direct involvement in specific cases of "abuse."

\section{CONCLUSION}

Since the governor's military, judicial, and economic roles brought him into frequent contact with local magistrates and councils, individual principes' collaboration (or failure to collaborate) with him, his staff, and other representatives of the Roman state could create or exacerbate divisions within communities. Though Cicero wishes to obscure these divisions, his descriptions of the procedures for administering justice, collecting taxes, and choosing the holders of high civic office in Sicily - all of which involved competition among local elites and the possibility of intervention by the governor-reveal multiple potential fault lines within communities.

Verres' interactions with Q. Minucius, a wealthy eques resident in Syracuse, illustrate the potential volatility of a governor's relations with provincial communities and individuals. Minucius appears at several points in the second actio,

\footnotetext{
${ }^{52}$ Venuleius successfully bid 8,000 medimnoi of wheat (triticum); the Thermitans offered him a payment of 7,000 modii of wheat and 2,000 sesterces (Genovese 1999: 20 and 41-43).
} 
though Cicero does not make any connection between these instances, perhaps not wishing to leave room for his audience to question Minucius' motives. Minucius testified against Verres at the first hearing (4.70), and he is mentioned at three points in Cicero's second set of orations: as the defender of Sopater of Halicyae in the trial at Syracuse, until he abandoned his client (2.68-80); as the unsuccessful bidder against Apronius for the tithes of the ager Leontinus at the annual auction in Syracuse (3.148-149); and as the host of Antiochus when the Syrian prince stopped over in Syracuse on his way home from Rome (5.61-70). It is hard to establish the chronology of these events, though it is likely that Sopater's trial and Antiochus' visit to Syracuse occurred in the first year of Verres' governorship (73 в.с.). In any case, it is notable that Q. Minucius, as the host of Antiochus, had also welcomed Verres into his home-the occasion on which he witnessed Verres' theft of the prince's gold and silver vessels (5.62-63). Perhaps Minucius' hostility to Verres developed later, out of his thwarted expectation of reciprocal beneficia from the governor in his activities as an advocate and as a decumanus.

Although every governor would have faced challenges broadly similar to Verres' in administering provincial legal and political affairs, events of previous decades, such as the Social War and the Sullan civil war, as well as more recent events, including the Sertorian war in Spain and the slave revolt of Spartacus in Italy, would have made for a particularly volatile atmosphere for Verres to step into in Sicily. The island's centrality in the Mediterranean meant that there would have been considerable movement through it, to and from Italy, Africa, Spain, and the East. It is not surprising that the governor encountered individuals —even Roman citizens like P. Gavius of Compsa (5.158-170)—of questionable identity and allegiance, especially in busy port cities like Syracuse and Messana. Additionally, at a time when the potential for food shortages at Rome was high, ${ }^{53}$ in the assessment and collection of the Sicilian grain tithe, the governor's interests - to provide as much grain to Rome, at the lowest price possible - were fundamentally in opposition to those of the aratores, who aimed to keep as much of their grain as possible, and to sell it in favorable market conditions at the highest price they could achieve.

In these circumstances, with such high potential for mutual mistrust and conflicts of interest between Roman authorities and provincials, it is not surprising that Verres was the object of individual and communal enmity; we might expect this even if he had not used his position to enrich himself at the expense of the Sicilians. ${ }^{54}$ The Sicilians could do little individually or collectively to counter directly the governor's rulings and policies while he was in his province; but after his term ended, they could strategically shift their allegiances and exploit

\footnotetext{
${ }^{53}$ As reflected in the passage of the lex Terentia et Cassia frumentaria, which authorized additional requisitions of Sicilian corn (3.163).

${ }^{54}$ Such restraint would have been unusual for a Roman governor, as Cicero acknowledges, and as Verres probably asserted in his own defense (3.205-206).
} 
multiple channels for recourse. If Verres' successor, L. Metellus, or other patroni would not assist them, they could expect that other ambitious and influential Romans-Cicero and perhaps indirectly, Pompey himself - would be willing to do so. ${ }^{55}$

Previous prosecutions of governors of Sicily in the quaestio de repetundis had a mixed record of success, and even after Cicero's victory, the amount that was actually recovered from Verres was probably small. Therefore, for Sicilians and other provincials, having their day in court in Rome was perhaps not as important as the consolidation of relationships with powerful Romans-and thus their own standing within and beyond their communities - that the mounting of an extortion prosecution entailed. ${ }^{56}$ Cicero's account of his treatment in Syracuse on his evidence-gathering trip earlier in 70 в.с. illustrates this fluidity of allegiances: shortly after they had attempted to tear down their monuments of Verres (2.160), the members of the council commissioned a monument for Cicero (in the form of a bronze decree commemorating his hospitium publice), in a meeting in the bouleuterion where statues of Verres and his son still stood $(5.142-145) .^{57}$

Classics Program

University of California, Davis

Davis, CA 95616

U.S.A.

lpfuntner@ucdavis.edu

BIBLIOGRAPHY

Alexander, M. C. 1990. Trials in the Late Roman Republic, 149 B.C. to 50 B.C. Toronto. Brunt, P. 1980. "Patronage and Politics in the 'Verrines'," Chiron 10: 273-289.

Butler, S. 2002. The Hand of Cicero. London.

Campagna, L. 2011. "Exploring Social and Cultural Changes in provincia Sicilia: Reflections on the Study of Urban Landscapes," in F. Colivicchi (ed.), Local Cultures of South Italy and Sicily in the Late Republican Period: Between Hellenism and Rome. Portsmouth, R.I. 161-183.

${ }^{55}$ As Nicols (2014: 181) notes, Cicero's ambition and relative lack of connections at the time of the trial may have made him more likely to assist the Sicilians than would traditional patrons like the Claudii Marcelli, who had more social capital to lose from involvement in a court case.

${ }^{56}$ In the fifty years preceding Verres' trial, we know of five trials of governors of Sicily out of a total of twenty-eight known extortion trials; three of these governors had served in Sicily during the slave revolt at the end of the second century. Alexander 1990: nos. 46 (M. Papirius Carbo, governor in 114?, convicted), 69 (L. Licinius Lucullus, governor in 104, convicted?), 70 (C. Servilius, governor in 102, convicted), 84 (M'. Aquillius, proconsular governor in 100/99, acquitted), and 131 (M. Aemilius Lepidus, governor in 80, charges dropped). Cicero claims that many (complures) former governors have been convicted, and only two (duo soli) acquitted (2.155). According to Plutarch, after Verres' conviction, the amount of his fine was so low that Cicero was accused of accepting a bribe for its reduction (Vit. Cic. 8; Miles 2008: 129-134).

${ }^{57} \mathrm{See}$, in general, Cristofori 2000 for statues and other honors for republican-era magistrates and Nicols 2014: 196-203 for these honors in the Verrines. 
Carcopino, J. 1914. La loi de Hiéron et les Romains. Paris.

Classen, C. J. 1980. "Verres Gehilfen in Sizilien nach Ciceros Darstellung," Ciceroniana 4: 93-111.

Covino, R. 2013. "Stasis in Roman Sicily," Electryone 1: 18-28.

Cristofori, A. 2000. "Il giudizio della società provinciale sugli amministratori romani in età repubblicana: considerazioni sulla documentazione,” in L. Mooren (ed.), Politics, Administration and Society in the Hellenistic and Roman World. Louvain. 55-75.

Damon, C. 1997. The Mask of the Parasite: A Pathology of Roman Patronage. Ann Arbor.

Della Corte, F. 1990. "Cicerone contro la 'cosca' di Erice," in G. Reggi (ed.), Cicerone oratore. Lugano. 65-78.

Deniaux, E. 2007. "Liens d'hospitalité, liens de clientèle et protection des notables de Sicile à l'époque du gouvernement de Verrès," in Dubouloz and Pittia 2007: 229-244.

Dilke, O. A. W. 1980. "Divided Loyalties in Eastern Sicily under Verres," Ciceroniana 4: $43-51$.

Dubouloz, J. and S. Pittia (eds.). 2007. La Sicile de Cicéron, Lectures des Verrines. Besançon.

Fournier, J. 2010a. "La lex Rupilia, un modèle du régime judiciaire provincial à l'époque républicaine?," Cahiers du Centre Gustave Glotz 21: 157-186.

— 2010b. Entre tutelle romaine et autonomie civique: L'administration judiciaire dans les provinces hellénophones de l'Empire romain (129 av. J.C.-235 apr.J.C.). Athens.

Frank, T. 1935. "On the Migration of Romans to Sicily," AJP 56: 61-64.

Frazel, T. D. 2009. The Rhetoric of Cicero's "In Verrem." Göttingen.

Gabba, E. 1959. "Sui senati della città Siciliane nell'età di Verre," Athenaeum 47: 304-320.

Genovese, M. 1993. “Condizioni delle 'civitates' della Sicilia ed aspetti amministrativocontributivi delle altre province nella prospettazione ciceroniana delle Verrine," Iura 44: 171-243.

— 1999. Gli interventi edittali di Verre in materia di decime sicule. Milan.

Greenwood, L. H. G. 1928-1935. The Verrine Orations. 2 vols. Cambridge, MA and London.

Gurd, S. 2010. "Verres and the Scene of Rewriting," Phoenix 64: 80-101.

Havas, L. 1969. "Verrès et les cités de Sicile," Acta Classica Universitatis Scientiarum Debreceniensis 5: 63-75.

Kantor, G. 2010. "Siculus cum Siculo non eiusdem civitatis: Litigation between Citizens of Different Communities in the Verrines," Cabiers du Centre Gustave Glotz 21: 187-204.

Lavan, M. 2013. Slaves to Rome: Paradigms of Empire in Roman Culture. Cambridge.

Maganzani, L. 2007. "L'editto provinciale alla luce delle Verrine: profili strutturali, criteri applicativi," in Dubouloz and Pittia 2007: 127-146.

Marinone, N. 1950. "Quaestiones Verrinae": Cronologia del processo di Verre. Torino.

Miles, M. 2008. Art as Plunder: The Ancient Origins of the Debate about Cultural Property. Cambridge.

Nicols, J. 2014. Civic Patronage in the Roman Empire. Leiden and Boston.

Pittia, S. 2004. "Les élites siciliennes au miroir du plaidoyer cicéronien contre Verres," in M. Cébeillac-Gervasoni, L. Lamoine, and F. Trément (eds.), Autocélébration des élites locales dans le monde romain. Clermont-Ferrand. 15-31.

2007. "La cohorte du gouverneur Verrès," in Dubouloz and Pittia 2007: 57-87. 
Prag, J. R. W. 2003. "Nouveau regard sur les élites locales de la Sicile républicaine," Histoire et Sociétés Rurales 19: 121-131.

- 2007a. "Ciceronian Sicily: The Epigraphic Dimension," in Dubouloz and Pittia 2007: 245-271.

- 2007b. "Auxilia and Gymnasia: A Sicilian Model of Roman Imperialism," JRS 97: 68-100.

- 2013. "Provincials, Patrons, and the Rhetoric of repetundae," in C. Steel and H. van der Blom (eds.), Community and Communication: Oratory and Politics in Republican Rome. Oxford. 267-283.

- 2014. "The Quaestorship in the Third and Second Centuries B.c.," in J. Dubouloz et al. (eds.), L'imperium Romanum en perspective: Les savoirs d'empire dans la République romaine et leur héritage dans l'Europe médiévale et moderne. Besançon. 193-209.

— and J. Crawley Quinn (eds.). 2013. The Hellenistic West: Rethinking the Ancient Mediterranean. Cambridge.

Rizzo, F. P. 1980. “'Principes civitatis' nelle Verrine: realtà civica e idealità ciceroniana,” Ciceroniana 4: 211-221.

Scuderi, R. 1996. "La raffigurazione ciceroniana della Sicilia e dei suoi abitanti: un fattore ambientale per la condanna di Verre," in C. Stella and A. Valvo (eds.), Studi in onore di Albino Garzetti. Brescia. 409-430.

Soraci, C. 2011. Sicilia frumentaria, il grano siciliano e l'annona di Roma, V a.C.-V d.C. Rome.

Steel, C. E. W. 2001. Cicero, Rhetoric, and Empire. Oxford.

— 2007. "The Rhetoric of the De Frumento," in J. R. W. Prag (ed.), Sicilia nutrix plebis Romanae: Rhetoric, Law, and Taxation in Cicero's Verrines. London. 37-48.

Vasaly, A. 1993. Representations: Images of the World in Ciceronian Oratory. Berkeley.

Wilson, R. J. A. 2000. "Ciceronian Sicily: An Archaeological Perspective," in C. Smith and J. Serrati (eds.), Sicily from Aeneas to Augustus. Edinburgh. 134-160. 